\title{
Economic Concentration in Functional Urban Areas of the Countries
}

\author{
Anna Oleshko, Liudmyla Sliusareva, Olga Chernova, Olena Kolyada, Polina Iurieva, \\ Olga Pazynich
}

\begin{abstract}
Urbanization processes are accompanied by economic concentration of resources in functional urban areas. At the same time, the level and dynamics of economic concentration differ depending on type, structure, location and national specifics of urban areas. The purpose of this article is to study economic aspects of urbanization and to develop the methodology for ranking functional urban areas by the level of their economic concentration. The survey is based on the rating approach, which is represented as a comparative analysis of indicators of economic concentration, followed by further definition of an integral indicator that helps us to rate urban areas. The results of urban areas ranking and grading by level of their economic concentration show that the highest level of economic concentration is found in Large metropolitan and metropolitan FUAs, which economic activities are dominated by financial services, as well as high-tech industry. The results of this rating can be used to justify directions of regional policy of polycentric development regarding regulation of scale of economic concentration in functional urban areas. It will also have a positive impact to effective distribution of resources within "center-periphery" economic space.
\end{abstract}

Index Terms: agglomeration, economic concentration, functional urban area, regional policy, spatial economics, territorial concentration, urbanization.

\section{INTRODUCTION}

The economic development of global and national economies is becoming increasingly spatially concentrated. Territorial concentration of labor, capital, markets, intellectual, financial and other resources is accompanied by concentration of economic activity in urban areas with a simultaneous slowdown in economic growth of peripheral areas. This worldwide trend is characterized by increased economic concentration in functional urban areas (FUAs) which consists of the city and its respectful commuting zone.

Revised Version Manuscript Received on October 15, 2019.

Anna Oleshko, Professor of Management Department, Kyiv National University of Technologies and Design, Ukraine, (Email: anna_oleshko@ukr.net)

Liudmyla Sliusareva, $\mathrm{PhD}$ in Economics, Associate Professor of Business Economics Department, University of the State Fiscal Service of Ukraine, Irpin, Ukraine. (Email: kaf.economik@gmail.com)

Olga Chernova, $\mathrm{PhD}$ in Economics, Associate Professor of International Economics Department. University of the State Fiscal Service of Ukraine, Ukraine, (Email: olga.chernova.online@gmail.com_

Olena Kolyada, PhD in Economics, Associate Professor of International Economics Department. University of the State Fiscal Service of Ukraine, Ukraine, (Email: Kolyada_ov@i.ua)

Polina Iurieva, $\mathrm{PhD}$ in Economics, Associate Professor of Internationa Economics Department, University of State Fiscal Service of Ukraine, Ukraine, (Email: IurievaPolina@gmail.com)

Olga Pazynich, PhD in Economics, Associate Professor of Management and International Economic Relations Department, Tavrida V.I. Vernadsky National University, Kyiv, Ukraine, (Email: olgapazynich@ukr.net)
In $2018,55 \%$ of the world's population resided in urban areas. By 2050 , more than $68 \%$ of the world's population is foreseen to reside in urban areas. [1].

Initially, features, causes and consequences of territorial economic concentration were identified in the framework of the Standort/Location theory (A. Weber) [2], the Central place theory (W. Christaller) [3], the Theory of circular cumulative causation (G. Myrdal) [4], the Growth pole theory (F. Perroux) [5] and are present in their modern interpretation within researches of P. Krugman [6; 7].

Modern spatial organization of socio-economic development is the result of interaction of two groups of factors: 1) factors contributing to the concentration of economic activity (centripetal forces), 2) factors contributing to dispersion (centrifugal forces) [8]. Consequently, nature of spatial distribution of economic activity is found within two limit states: with full concentration in one center, which is defined as monocentric development, and with more uniform dispersion throughout the whole territory, which is characterized as polycentric development. The advantages of polycentric territorial development accompanied by mechanisms of economic concentration in urban areas are manifested in research works $[9 ; 10 ; 11]$. At the same time, relatively more monocentric regions have higher GDP per capital than their more polycentric counterparts and at the country level polycentricity is associated with higher GDP per capital [12]. Henderson J. emphasizes the demand to determine and achieve the optimal level of urbanization [13].

The study of economic concentration will show specific features depending on chosen territorial level: intra-urban (micro-level), regional (meso-level), national (macro-level) or supranational (mega-level).

At the national level, economic concentration occurs as a result of complex interaction of centripetal and centrifugal agglomeration forces, and is observed in outpacing growth of production, trade, construction, transport facilities, infrastructure, social standards, migration to the city (or core) at functional urban areas etc. Bottlenecks related to definition of economic concentration of functional urban areas taking into account their size and comparative interpretation of results with the possibility of their application in the state regional policy remain unsolved. 


\section{METHODOLOGY}

Various methodologies and groups of indicators are used to identify and determine effectiveness of functional urban areas.

According to the OECD methodology, functional urban area is defined in four steps: 1. Identify an urban centre: a set of contiguous, high density (1,500 residents per square kilometer) grid cells with a population of 50,000 in the contiguous cells; 2 . Identify a city: one or more local units that have at least $50 \%$ of their residents inside an urban centre; 3. Identify a commuting zone: a set of contiguous local units that have at least $15 \%$ of their employed residents working in the city; 4. A functional urban area is the combination of the city with its commuting zone [14].

In order to determine the hierarchy of cities and urban areas, OECD researchers use the "rank-size" indicator, which is calculated as the absolute value of the angular coefficient of the regression line within the natural logarithm of city population (settlement), the natural logarithm of its rank in population and the primacy rate indicator, which is expressed as a proportion of the largest city population to the countrywide population [12].

Territorial population density is expressed in terms of the ratio of territory population to its area size, and economic density is expressed as the volume of production per unit area of the territory or GVA per $1 \mathrm{sq}$. km. [15]. The existence of a close correlation between population density and production density is determined by the World Bank studies [16]. At the same time, this approach is limited to determining the level of economic concentration, since region within developing countries, which are leading in territorial density and are more densely populated, often show lower levels of economic density. To eliminate this flaw, some researchers carry out the procedure of density reduction [17]. However, this approach does not take into account the productivity of labor forces, which leads to distortion of results and makes it impossible to evaluate urban areas by the level of their economic concentration. To eliminate this flaw, along with the indicator of economic density, it is advisable to consider GVA index per person as an aggregate indicator that takes into account 10 types of economic activity.

For national economy, Formula 1 is used to rank urban areas on their level of economic concentration:

$$
R_{J}=\sum_{i=1}^{n} \frac{P_{i J}-P_{\min i}}{P_{\text {maxi }}-P_{\min i}}
$$

where $\mathrm{R}_{J}$ is the sum of ranking scores of the level of economic concentration of $\mathrm{J}$ of Functional urban area;

$P_{i}$ - value of $i$ indicator of $j$ indicator of Functional urban area;

$\mathrm{P}_{\text {maxi }}, \mathrm{P}_{\text {mini }}$ - maximum and minimum value of the $\mathrm{i}$ indicator of economic concentration.

According to the results of calculations, the integral rating score of $\mathbf{J}$ of Functional urban area $\left(I_{E C_{J}}\right)$ as an arithmetic mean of the sum of urban area rating scores in terms of economic density and GVA per capita (2):

$$
I_{E C_{J}}=\frac{R_{J}}{2}=\frac{R_{E D_{J}}+R_{G V A_{J}}}{2},
$$

where $R_{E D_{J}}$ is a ranking score of economic density of $\mathrm{J}$ of Functional urban area;

$R_{G V A_{J}}$ - ranking score of GVA per capita of J of Functional urban area.
The rank indices of economic density, GVA per capita and economic concentration range from 0 to 1 . The higher the value of the index, the higher the level of economic concentration of urban area.

Described methodology will allow us to identify and rank the urban areas of the country according to the degree of their economic concentration.

\section{RESULTS AND DISCUSSION}

Identification of Functional urban areas in Europe conducted by OECD researchers shows signs of polycentric territorial development. At determining Functional urban areas according to OECD methodology, such areas are divided into four kinds: 1) Small FUAs, with population between 50,000 and 100,000; 2) Medium-sized FUAs, with population between 100,000 and 250,000; 3) Metropolitan FUAs, with population between 250,000 and 1.5 million; 4) Large metropolitan FUAs, with population above 1.5 million [18].

As Fig. 1 shows, Metropolitan and Medium-sized FUAs are dominant for European countries. The largest number of Functional urban areas is in Germany (96), Britain (95), France (86), Italy (84), and Spain (81). Moreover, in all EU countries without exception, Metropolitan or Medium-sized FUAs are dominant within the structure of Functional urban areas. More urbanized countries in recent years show higher GDP growth rates, as identified by OECD research [12].

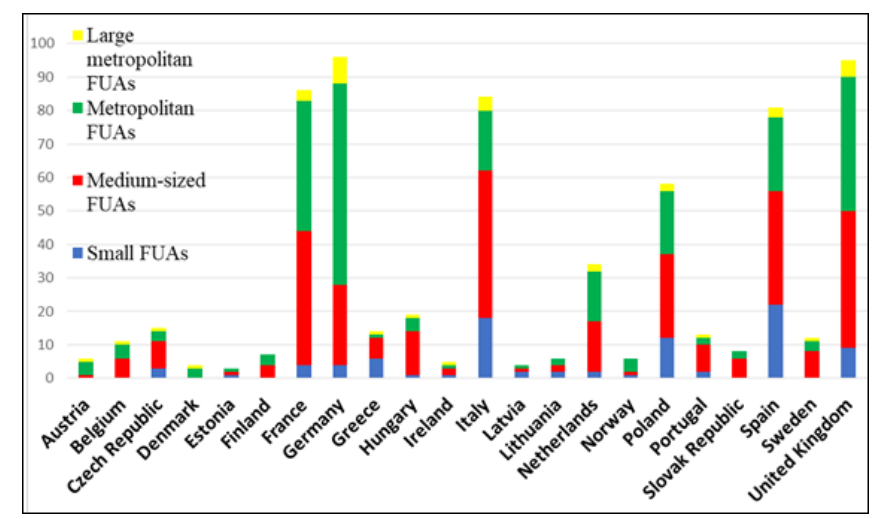

Fig. 1. Functional urban areas in EU

At the same time, there is a difference in the territorial development of developed and developing countries. Economies of developing countries show dynamic urbanization, which is characterized by a faster growth of territorial density (number of urban population is growing) in Large metropolitan FUAs in relation to the indicator of economic density. At the same time, new urban areas are not formed, which leads to monocentric territorial development.

Ukraine, as a EU associate member, belongs to the countries with emerging markets. Therefore, the impact of EU urbanization on the territorial development of Ukraine is significant.

Using the OECD methodology, 32 FUAs were allocated in Ukraine, 22 of which are regional administrative centers (excluding Autonomous Republic of Crimea and Joint Forces Operation zone). 
Urban areas that are not regional administrative centers, such as Mariupol, Kramatorsk, Kryvyi Rih and others are large industrial zones.

As can be seen from Table.1 the vast majority of FUAs-administrative centers of Ukraine belong to Metropolitan ones (16). There is one Large metropolitan city
- Kyiv, which is quite natural, since the capital is the financial and commercial center of Ukraine, and the level of GRP per capita is 12 times higher than in the most depressed area of Chernivtsi Oblast. All Medium-sized FUAs (5) are situated on western non-industrial territories.

Table- I: Functional urban areas-Administrative centers in Ukraine

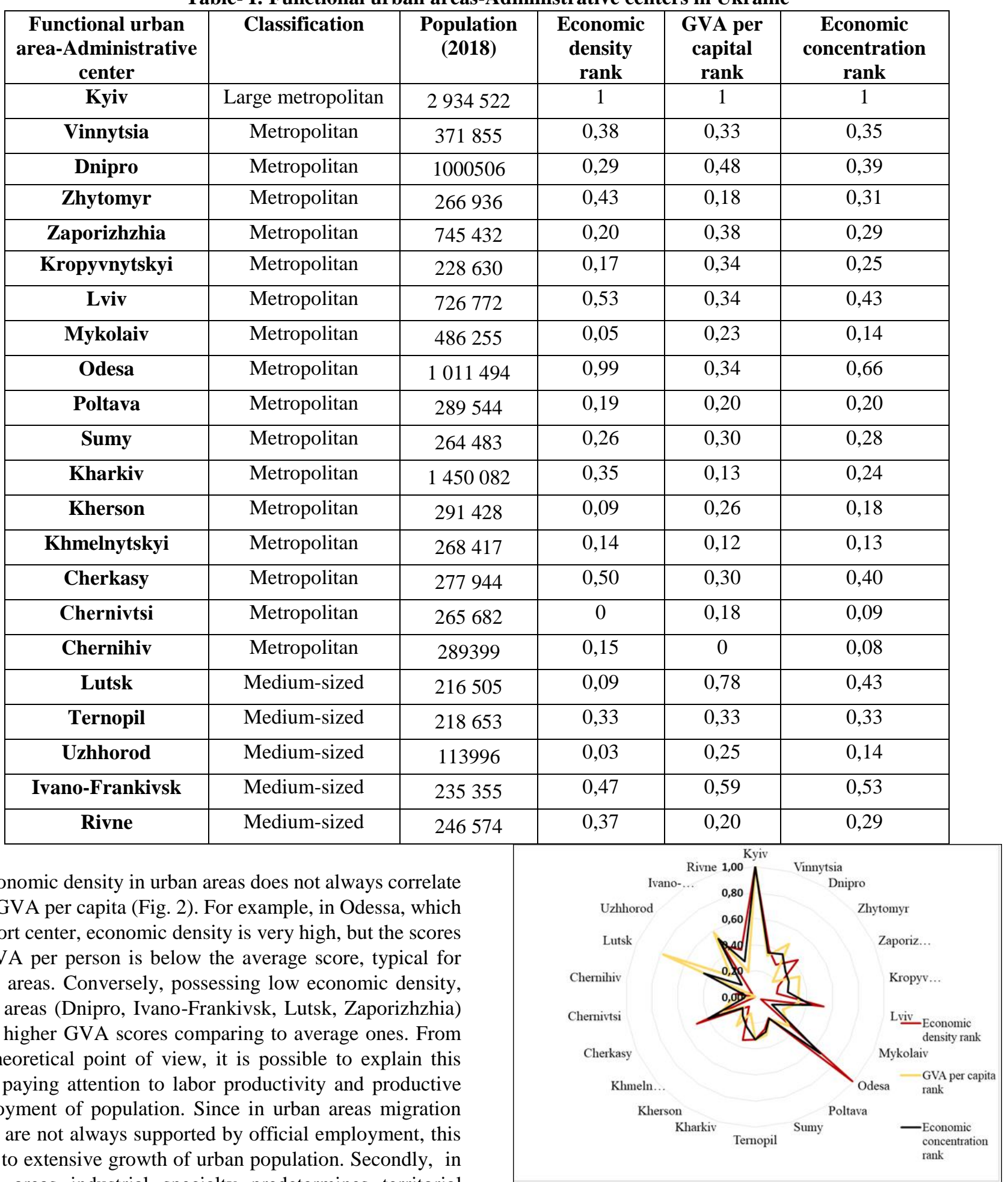
urban areas industrial specialty predetermines territorial location of industries with different levels of added value: usually high-tech industries have quite high added value, and agro-industrial ones - low value. This leads to an increase of economic concentration in high-tech zones and its low level in production zones.
Fig. 2. Ranking of functional urban areas of Ukraine by economic concentration 
The results of economic density and GVA per capita calculations according to the given methodology allowed us to rank FUAs by the level of economic concentration and to define economically developed and undeveloped cities. In addition, a comparative analysis of the results of economic density and regional GRP dynamics calculations [19] shows that the highest rates of GRP growth are observed in regions where urban areas with high economic density are located.

\section{CONCLUSIONS}

The methodology and calculation of the level of FUAs economic concentration, as well as their further ranking by level allow us to identify cities-points of economic growth taking into account the productivity of capital and labor.

It was found that growing population migration to FUAs (population growth) does not always lead to a corresponding increase in production per capita. That is, territorial concentration is observed (growth of territorial density), but growth of economic density, which is characterized by production growth per unit area does not occur. The highest level of economic concentration is found in Large metropolitan and metropolitan FUAs, whose economic activities are dominated by provision of financial services and high-tech industry.

The results of the study appears to be an analytical basis for development and implementation of state policy aimed at supporting of polycentric development at the macroeconomic level.

\section{ACKNOWLEDGMENT}

This study is an output of the project the International economy Department of University of State Fiscal Service of Ukraine "The development of the world economy in the conditions of the fourth industrial revolution", project number $0119 \mathrm{U} 001557$.

\section{REFERENCES}

1. United Nations, Department of Economic and Social Affairs, Population Division (2019). World Urbanization Prospects 2018: Highlights (ST/ESA/SER.A/421)

2. Weber A. On the Location of Industries. Pure theory of Standort. M.: Publishing house Knyha, 1926. 223 p.

3. Christaller, W. Die zentralen Orte in Suddeutschland. Jena: Gustav Fischer, 1933. 331 p.

4. Myrdal, G. Economic theory and under-developed regions. London : Gerald Duckworth \& Co, 1959. 167 p.

5. Perroux, F. L'economie du XXe siecle. Paris : Presses Universitaires de France, 1961. 765 p.

6. Krugman, P. Geography And Trade. Cambridge, MA, USA. The MIT Press, 1991. 156 p.

7. Krugman P. Increasing returns and economic geography. Journal of Political Economy. 1991. vol. 99. PP. 483-499.

8. Cervero, R. Efficient urbanisation: economic performance and the shape of the metropolis. Urban Studies, 2001. vol. 38(1). PP 1651-1671.

9. Burger, M. and E. Meijers. Form follows function? Linking morphological and functional polycentricity. Urban Studies, 2012. vol. 49(5). PP. 1127-1149.

10. Green N. Functional polycentricity: A formal definition in terms of social network analysis. Urban Studies, 2007. vol. 44 (11). PP 2077-2103.

11. Parr J. The Polycentric Urban Region: A Closer Inspection. Regional Studies. 2004. vol. 38. PP. 231-
240.

12. Brezzi M., Veneri P. Assessing Polycentric Urban Systems in the OECD: Country, Regional and Metropolitan Perspectives. European Planning Studies. 2015. Vol. 23. PP. 1128-1145.

13. Henderson, J. V. (2003), "The urbanization process and economic growth: The so-what question", Journal of Economic Growth 8(1): 47-71.

14. Dijkstra L., Poelman H. and Veneri P. The EU-OECD definition of a functional urban area. July 2019. Available: https://www.oecd.org/cfe/regional-policy/the\%20eu-oecd $\% 20$ definition $\% 20$ of $\% 20$ a $\% 20$ functional $\% 20$ urban $\% 20$ a rea.pdf

15. Golvazin O.M. National-level polycentricity of territorial development in Ukraine and OECD countries. East European Science Journal, 2016. vol. 11 (15). PP. 50-55.

16. Reshaping Economic Geography. World Development Report. 2009.The World Bank.383p.

17. Romaniuk S. A. Economic density as an indicator of urban development. Efektyvna ekonomika No. 1, 2013. Available:

http://www.economy.nayka.com.ua/?op=1\&z=1770

18. OECD (2012), Redefining "Urban": A New Way to Measure Metropolitan Areas, OECD Publishing. http://dx.doi.org/10.1787/9789264174108-en

19. Gross regional product (2004-2018). State Statistics Service Of Ukraine. Available: http://www.ukrstat.gov.ua/

\section{AUTHORS PROFILE}

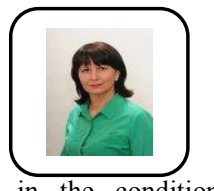

Anna Oleshko, Professor of Management Department, Kyiv National University of Technologies and Design, Ukraine, e-mail: anna_oleshko@ukr.net

She is the performer of several research works, in particular, «Ensuring the economic security of enterprises in the conditions of globalization» by the International economics Department of University of State Fiscal Service of Ukraine. An author or co-author of over 150 scientific publications, she also serves as a reviewer in several referred international and national journals. She is a member of several professional associations and has also presented at various international conferences. Her research interests are state economic policy, regional management and urbanization.

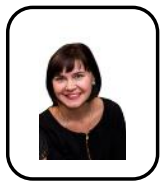

Liudmyla Sliusareva, $\mathrm{PhD}$ in Economics, Associate Professor of Business Economics Department, University of the State Fiscal Service of Ukraine, Irpin, Ukraine. Email: kaf.economik@gmail.com

She is the performer of several research works, in particular, «Ensuring the economic security of enterprises in the conditions of globalization» by the International economics Department of University of State Fiscal Service of Ukraine. An author or co-author of over 65 scientific publications and has also presented at various international conferences. Her research interests are international and regional marketing, logistics and International economics.

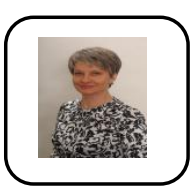

Olga Chernova, $\mathrm{PhD}$ in Economics, Associate Professor of International Economics Department, University of the State Fiscal Service of Ukraine, Ukraine, e-mail: olga.chernova.online@gmail.com

She is the performer of several research works, in particular, «Ensuring the economic security of enterprises in the conditions of globalization» by the International economics Department of University of State Fiscal Service of Ukraine. An author or co-author of over 60 scientific publications and has also presented at various international conferences. Her research interests are problems of the world economy, transnationalization, globalization 
Olena Kolyada, $\mathrm{PhD}$ in Economics, Associate Professor of International Economics Department. University of the State Fiscal Service of Ukraine, Ukraine, e-mail: Kolyada_ov@i.ua

She is the performer of several research works, in particular, «Ensuring the economic security of enterprises in the conditions of globalization» by the International economics Department of University of State Fiscal Service of Ukraine. An author or co-author of over 50 scientific publications. She is a member of professional association. Her research interests: middle class, small business in a transformational economy

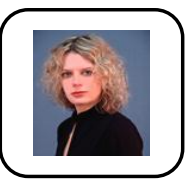

Polina Iurieva, $\mathrm{PhD}$ in Economics, Associate Professor of International Economics Department, University of State Fiscal Service of Ukraine, Ukraine, e-mail: IurievaPolina@gmail.com

She is the performer of several research works, in particular, «Ensuring the economic security of enterprises in the conditions of globalization» by the International economics Department of University of State Fiscal Service of Ukraine. An author or co-author of over 35 scientific publications, she also presented at various international conferences. Her research interests are international trade, world commodity markets, foreign economic activity of Ukraine.

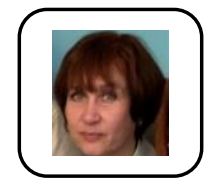

Olga Pazynich, $\mathrm{PhD}$ in Economics, Associate Professor of Management and International Economic Relations Department, Tavrida V.I. Vernadsky National University, Kyiv, Ukraine, e-mail: olgapazynich@ukr.net.

She is the performer of several research works, in particular, «Ensuring the economic security of enterprises in the conditions of globalization» by the International economics Department of University of State Fiscal Service of Ukraine. She is a member of the Professional Association of International Economists and has also presented at various international conferences. An author or co-author of over 50 scientific publications. Her research interests are international management, international business activities 